How to cite

Yaki, A. A., Saat, M. R., Sathasivam, V. R., \& Zulnaidi, H. (2019). Enhancing science achievement utilising an integrated STEM approach. Malaysian Journal of Learning and Instruction, 16(1), 181-205.

\title{
ENHANCING SCIENCE ACHIEVEMENT UTILISING AN INTEGRATED STEM APPROACH
}

\author{
Akawo Angwal Yaki, ${ }^{1}$ Rohaida Mohd Saat, Renuka V. \\ Sathasivam \& Hutkemri Zulnaidi \\ Faculty of Education, University of Malaya, Malaysia

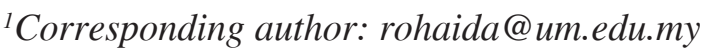

Received:18 July 2018 Revised: 14 February 2019 Accepted: 26 March 2019

\begin{abstract}
Purpose - The integrated science, technology, engineering and mathematics (STEM) education has been reported to improve students' science achievement. Nevertheless, few studies have focused on how this approach affected different ability groups. Lack of equity or the presence of achievement gap can be detrimental because they can reduce medium and low-ability students' interest in science, which in turn can affect national development. Thus, the purpose of this study is to determine the main and the interaction effects of integrated science, technology, engineering and mathematics (ISTEMA) on students' science achievement and how this approach affects students with different academic abilities.
\end{abstract}

Methodology - The research adopted a $2 \times 3$ factorial design. The sample size consisted of 100 Nigerian science students from Year 11. A total of 51 students with different academic abilities (low, medium and high) were assigned randomly to an experimental group. The experimental group was taught genetics using a fivephased iterative ISTEMA process. Pre-test and post-test data were collected using 40 multiple-choice questions adopted from a national high-stakes examination. Analysis of covariance, paired 
sample $t$-test and one-way analysis of variance were utilised in the data analysis.

Findings - Findings for research question one revealed a main significant difference in science achievement between year 11 students who learned using ISTEMA and those using traditional methods. No significant interaction effect was observed between the instructional approach and students' academic abilities, that is, students' academic abilities and the instructional approach did not interact to enhance students' achievement. The findings for research question two indicated that high, medium and low academic-ability students benefitted; however, students with low academic abilities had the highest mean gain.

Significance - Findings in this study have revealed empirically that the ISTEMA, as an instructional approach, has the potential to close the academic achievement gap. The findings may also serve as a guide for policymakers to promote STEM education in schools.

Keywords: Genetics, science achievement, stem education and students' academic ability.

\section{INTRODUCTION}

Promoting meaningful and efficient learning of science has been an important objective of many educational systems (Kostiainen et al., 2018). However, the cultivation of meaningful and efficient science learning does not depend solely on teachers' abilities but also on instructional approaches and the learning environment (Karpudewan \& Chong, 2017) because students respond differently to different instructional approaches based on their academic abilities. Therefore, an instructional approach should involve and assist all students in achieving their desired learning objectives and ultimately increase science achievement. Nevertheless, achieving instructional equity amongst high-, medium- and low-ability students is a persistent challenge and a paramount concern for educators (Gambari, James, \& Olumorin, 2013; Schofield, 2010). Therefore, focus should be given to instructional strategies that can address students' learning differences. Thalib, Corebima, and Ghofur (2017) emphasised that educators should employ student-centred instructional approaches 
that will enhance mastery of the learning content whilst catering to individual learning differences.

Students are generally categorised into ability groups based on their intelligence quotient or academic achievements, which is likewise referred to as ability class (high, medium and low). Previous literature has reported achievement gaps amongst students at national and international levels in traditional learning environments (Gambari et al., 2013; Han, Capraro, \& Capraro, 2014; Yu, She, \& Lee, 2010). Teachers utilising traditional approaches believe that teaching low academic-ability students, complex and abstract learning content is not appropriate because they may not be able to cope with complex tasks (Yu et al., 2010). High-ability students perform better than medium- and low-ability students in science (Gambari et al., 2013; Raes, Schellens, \& De Wever, 2013). The lack of equity or the presence of achievement gaps between high-, medium-, and lowability students, especially in traditional classroom environments, could negatively affect the interest of low- and medium-ability science students and their subsequent choice of STEM careers (Lin \& Lin, 2016).

Although numerous researchers have focused on the factors that may be responsible for the achievement gap between students with different academic abilities with the intention of reducing it, the gap still persists (Schofield, 2010; Steenbergen-Hu, Makel, \& Olszewski-Kubilius, 2016). Shahali, Halim, Rasul, Osman, and Zulkifeli (2017) suggested that raising the science achievement of all students is an absolute necessity if they are to compete and remain competitive in the global market. Therefore, further research on equity in science achievement is necessary. Reducing this gap may require the adaptation and implementation of an innovative instructional approach that can address students' individual learning needs and actively engage them in the learning process (Kermani, 2017; Sailin \& Mahmor, 2018). One such strategy is the integrated STEM-based approach (ISTEMA), which may enhance students' active engagements leading to a reduction in the achievement gap amongst different academic-ability groups (Arıkan, 2018; Shahali et al., 2017).

STEM education is an interdisciplinary instructional strategy that integrates science, technology, engineering and mathematics to solve ill-structured problems by likening it to real-life professional 
processes (Bybee, 2010; Sanders, 2009). Tsai, Chung and Lou (2018) reported that STEM approaches could be implemented using inquiry- and cooperation-based approaches to improve students' proficiencies in science. STEM-based approaches have the potential to increase students' abilities in integrating knowledge and skills and to improve problem-solving skills in open-ended problems (Chang \& Yang, 2014; Treacy \& O'Donoghue, 2014). STEMbased approaches make learning disciplines highly relevant and meaningful to students (Stohlmann, Moore, \& Cramer, 2013).

The literature has revealed mixed findings regarding the effects of STEM-based approaches on student achievement (Berland, Steingut, \& Ko, 2014; Guzey, Harwell, Moreno, Peralta, \& Moore, 2017). Several studies have reported that STEM-based approaches improve student achievement in science (Stohlmann, Moore, \& Roehrig, 2012; Thomas, 2013) because it is a non-traditional instructional strategy that provides opportunities for active engagement (Krajcik, 2015). Guzey et al. (2017), in their study on the effects of designbased STEM instruction on student achievement in middle school, found significant learning gains in physical science content but no significant learning gains in life science and mathematics. They highlighted that adding engineering casually into science instruction did not promote meaningful learning but addressed the absence of meaningful integration. Acara, Tertemizb, and Taşdemirc (2018) adopted a quasi-experimental design to determine the effects of STEM-based instruction on mathematics and science achievements. Their findings indicated that students improved their science scores. They recommended further research on STEM approaches and their effects on students' academic abilities (high, medium and low) to contribute to the existing literature.

In contrast, James (2014) found no significant differences between groups instructed with STEM and non-STEM. Lachapelle et al. (2011) found no significant differences between the post-test scores of students who participated in STEM-based engineering design integration and the control group in a science unit on organisms.

Sanders (2009) advocated that STEM education should include the objectives of at least one STEM subject, suggesting a science or mathematics learning objective in engineering or technology as an instructional medium and thus, the present study considered genetics as the science instructional content. Recent developments in the field of genetics, such as genetically modified organisms and 
cloning, have raised fundamental educational, ethical and financial questions and thus, the present generation of students need to equip themselves with a comprehensive understanding of genetics (Danmole \& Lameed, 2014). However, the literature has revealed that teachers and students experience difficulties in teaching and learning genetics (Agboghoroma \& Oyovwi, 2015; Atilla, 2012; Williams, Montgomery, \& Manokore, 2012). Factors responsible for these learning difficulties include the abstract nature of genetics because of its cellular processes (Agboghoroma \& Oyovwi, 2015; Atilla, 2012) and multidisciplinary aspects, involving probabilities in mathematics and applications in bioengineering (Chu \& Reid, 2012). Therefore, learning of genetics from a traditional approach, as observed in many classrooms, could have contributed to these learning difficulties. Based on these findings, students' achievement in science (genetics) continues to be unacceptable (Danmole \& Lameed, 2014).

Accordingly, because of its multidisciplinary nature, the ISTEMA could provide an efficient way to study genetics. ISTEMAs are generally characterised by group discussions, hands-on and mindson activities to create concrete genetic processes, thereby increasing the likelihood of improving students' academic achievement in genetics (Galloway \& Anderson, 2014; Mandusic \& Blaskovic, 2015).

Danmole and Lameed (2014) examined the effects of hands-on activities on genetics achievement amongst secondary school students through annotated drawings. Tests on genetics and student interviews were utilised to collect data. The results revealed that the annotated drawing strategy (in the experimental group) had a significant effect on students' achievement in genetics. (Williams et al., 2012) conducted a study 'from phenotype to genotype', exploring middle-school students' understanding of genetic inheritance in a web-based science inquiry environment. The results revealed that the treatment had a significant effect because significant gains were observed from comparisons made between pre-tests and post-tests.

\section{CONTEXT OF THIS STUDY: ISTEMA}

The engineering design process (EDP) is the foundation for discipline integration (English, 2016), which is a critical component 
of the new trend in meaningful science instruction (Guzey, Moore, $\&$ Morse, 2016). The approach provides students with exciting learning experiences that are less disjointed and relevant for solving actual problems (Moore et al., 2014). Thus, the EDP was adopted in the present study as the platform for science and mathematics integration. The EDP generally consists of several iterative steps (English, King, \& Smeed, 2016; Lottero-Perdue, Roland, Turner, \& Pettitt, 2013; Martinez \& Stager, 2013). For instance, Martinez and Stager (2013) utilised three phases, namely, think, make and improve, which were adopted to engage students actively in creative hands-on activities. Consequently, for the ISTEMA, a fivephased iterative design process was created, namely, engaging in the problem, generating ideas, designing solutions, evaluating and improving, and communicating the findings. Table 1 presents the five phases of the ISTEMA utilised in this study.

Table 1

Phases of the ISTEMA Iterative Proces

\begin{tabular}{lll}
\hline Phase & Description & STEM discipline \\
\hline $\begin{array}{l}\text { Engage in the } \\
\text { problem }\end{array}$ & $\begin{array}{l}\text { Highlight the components and state } \\
\text { the requirements of the problem and } \\
\text { constraints, } \\
\text { focus on the cause(s) of the problem. }\end{array}$ & $\begin{array}{l}\text { science and } \\
\text { engineering }\end{array}$ \\
\cline { 2 - 3 } & Group collaboration on the problem. & \\
\hline Generate ideas & $\begin{array}{l}\text { Generate ideas on genetic laws } \\
\text { (Mendel's first and second laws). }\end{array}$ & science (genetics) \\
\cline { 2 - 3 } & $\begin{array}{l}\text { Apply principles of combining } \\
\text { dominant and recessive characters, } \\
\text { among others. }\end{array}$ & $\begin{array}{l}\text { algebraic thinking } \\
\text { and probability } \\
\text { (mathematics) }\end{array}$ \\
& $\begin{array}{l}\text { Apply principles of expressing } \\
\text { genotypes and phenotypes. }\end{array}$ & \\
\cline { 2 - 3 } & $\begin{array}{l}\text { Collect information on genetic } \\
\text { engineering procedures, extraction, } \\
\text { isolation and insertion. }\end{array}$ & $\begin{array}{l}\text { engineering and } \\
\text { technology }\end{array}$ \\
\cline { 2 - 3 } & $\begin{array}{l}\text { Brainstorm on the best idea. } \\
\text { Sketch ideas. }\end{array}$ & \\
\hline Design & &
\end{tabular}

(continued) 


\begin{tabular}{lll}
\hline Phase & Description & STEM discipline \\
\hline & $\begin{array}{l}\text { Transform ideas into 2D or 3D } \\
\text { models using local materials; } \\
\text { measure, cut and stick materials, etc. } \\
\text { to build an imaginary 3D modified } \\
\text { hare. }\end{array}$ & $\begin{array}{l}\text { mathematics and } \\
\text { technology }\end{array}$ \\
\cline { 2 - 3 } & Group project. \\
\hline $\begin{array}{l}\text { Evaluate and } \\
\text { improve }\end{array}$ & $\begin{array}{l}\text { Evaluate the solution, such as, } \\
\text { whether the requirements are met } \\
\text { and the influencing factors. }\end{array}$ \\
\hline $\begin{array}{l}\text { Communicate } \\
\text { the findings }\end{array}$ & $\begin{array}{l}\text { Reflect on the entire process and } \\
\text { present the findings. }\end{array}$ \\
\hline
\end{tabular}

The five phases ensured that the learning objectives of one discipline (genetics, science) were integrated with other disciplines to enhance the understanding of the learning content (Bryan et al., 2016; Kertil $\&$ Gurel, 2016). Despite being regarded as an important instructional approach, science teachers still experience difficulties implementing ISTEMA (Osman \& Saat, 2014; Rinke et al., 2016). Therefore, instructional materials describing each phase of the ISTEMA were prepared in the present study. The instructional materials assisted the Year 11 science teachers in implementing the ISTEMA for topics in genetics.

The instructional materials consisted of elements which formed the cornerstone of the ISTEMA. The elements were based on constructivist theory that ensured student-centred instruction wherein students engaged actively in the learning process and learning occurred in a social context. Thus, the learning process included open-ended and actual problems, questions, hands-on and minds-on activities and inquiries. Moreover, the instructional materials stressed teamwork and collaboration with the teacher acting as the facilitator. All the elements combined for the ISTEMA instructional materials were supported by research. For example, the open-ended problems provided students with opportunities to generate ideas from STEM disciplines and to integrate them to find solutions (Cox, Reynolds, Schunn \& Schuchardt, 2016; Treacy \& O'Donoghue, 2014). Bybee (2010) highlighted that learning should be built around a big idea or problem that is relevant to the students' daily lives. Problems relevant to the students' personal and social 
lives may arouse their curiosity in the subject matter (Bryan et al., 2016). Therefore, the Year 11 Nigerian students were presented with an open-ended problem on the African savannah hare, which is a relevant part of their lives.

The Hare is a wild rabbit with an estimated length of between 41 and $58 \mathrm{~cm}$. This animal is endangered by annihilation, and your group is contacted by a zoologist to engineer a unique hare that will benefit society.

To support the students' engagements in learning, tools were provided, such as the KWLH (for assessing what the students know, what the students want to find out, what the students learned and how the students learned it). During the introduction, the students were given worksheets with the KWLH table to complete (Table 2).

Link the problem to pre-existing knowledge using the KWLH sheet on what we know about the problem, what we want to find out, what we learned, and how we learned it.

Table 2

KWLH Worksheet

What we know What we want to What we learned How we

about the problem find out learned it

The purpose of this study is to determine the main and interaction effects of the ISTEMA on students' science achievement and the effects of the ISTEMA on students with different academic abilities. The objectives of the study are presented as follows.

\section{RESEARCH OBJECTIVES}

This study seeks to achieve the following objectives: 
1. Identify significant main and interaction effects amongst Year 11 science students utilising ISTEMA and traditional methods;

2. Identify significant differences in science achievement amongst high, medium and low academic-ability students in the ISTEMA (experimental) group.

\section{RESEARCH QUESTIONS}

The following research questions are stated to guide the study.

1. Are there any significant main and interaction effects amongst Year 11 science students utilising ISTEMA and traditional methods?

2. Are there any significant differences in science achievement amongst high, medium and low academic-ability students in the ISTEMA (experimental) group?

\section{METHODOLOGY}

A quantitative design was adopted, specifically, a $2 \times 3$ factorial design with two independent variables (ISTEMA and traditional instructional groups) and three levels (high, medium and low) of student academic abilities.

\section{Population and Sample}

The population of this study were Year 11 (or senior secondary school) science students from the Federal Unity Schools in Niger State, Nigeria. Two Federal Unity Schools were assigned randomly as experimental and control groups. The sample size was 100 students. The experimental group consisted of 51 students who were randomly selected. The number of students for the high-, mediumand low-ability groups was 15, 20 and 16, respectively. The control group consisted of 49 science students, with 15 in the high-ability group, 19 in the medium-ability group and 15 in the low-ability group. In this study, the average science achievement from the previous year was utilised to classify students as follows: $\geq 70 \%$ 
as high, $\geq 50-69 \%$ as medium and $\leq 49$ as low academic ability (Han et al., 2014).

\section{Instrument}

A science achievement test consisting of 40 multiple-choice questions on genetics were adapted from the West African Senior Secondary Certificate Examination (WASSCE). The questions were chosen from tests conducted between 2012 and 2016. An example of a question in the science achievement test is presented in Figure 1 .

A man heterozygous for albino gene marries a woman who is al so heterozygous for the gene. Both have normal skin colour. The probability that they will have al bino child is:
a). $1 / 3$
b). $1 / 4$
c). $4 / 4$
d). $2 / 4$
e). $2 / 3$

Figure 1. Genetic Question Adapted from the WASSCE.

The science achievement test was pilot-tested to determine its reliability utilising the split-half method. The reliability coefficient was 0.84 , which was considered suitable for this study (Hair, Black, Babin, \& Anderson, 2010).

\section{Intervention}

The intervention lasted for eight weeks. During the first week, a pre-test was administered for both groups. The students in the experimental group were divided into groups with five students each. The groups were heterogeneous in ability and gender. The students were instructed using a five-phased ISTEMA iterative process with the assistance of the instructional materials. The teachers in the experimental group were trained on the ISTEMA and on the instructional materials. The students under the ISTEMA worked individually within a specified time and met at the end of each phase to share their ideas. Each student was given an ISTEMA worksheet to record his/her ideas before re-joining his/her group to share and defend his/her ideas. Group members probed one another 
for justifications before reaching a consensus on the best idea. The control group was instructed with traditional teaching methods, which were based on teachers' explanations from the textbooks and notes. At the end of the eight weeks, a post-test was administered to both groups.

\section{Data Analysis}

Data collected from pre-tests and post-tests were screened for the assumption of analysis of covariance (ANCOVA) and analysed based on the stated research questions. Mean, standard deviation and ANCOVA were utilised to analyse the data.

\section{RESULTS}

\section{Comparison of Pre-Test Scores between Experimental and Control Groups}

First, a science achievement pre-test was administered to both groups (experimental and control) before the start of the intervention. Data from the pre-test were utilised to determine similarities between the two groups before the intervention (Table 3).

Table 3

Pre-Test Results of Experimental and Control Groups

\begin{tabular}{lccccccl}
\hline Variable & $\mathrm{N}$ & $\mathrm{df}$ & $\overline{\mathrm{x}}$ & $\mathrm{SD}$ & t-value & P-value & Remarks \\
\hline Experimental & 51 & 98 & 30.45 & 6.39 & & & \\
& & & & & $-2.40^{*}$ & 0.01 & $\begin{array}{l}\text { Signifi- } \\
\text { cant }\end{array}$ \\
Control & 49 & & 33.59 & 6.66 & & & \\
\hline * Significant at $p<05$ & & & & & &
\end{tabular}

Table 3 presents the pre-test results and the means of the experimental and control groups, which are 30.45 and 33.59 , respectively. These results indicated that the means of the two groups were significantly different $t(98)=2.40, p<.05$, thereby indicating that the two groups were not similar with regard to their science achievement before the intervention. Therefore, the pre-test scores for genetics were 
utilised as covariates to mediate the initial differences between the two groups.

\section{Post-Test Results}

This section determines the effects of the intervention by comparing the post-test data of the students instructed with the ISTEMA and the students instructed with traditional teaching methods. The ANCOVA is valid when the assumptions of normality and homogeneity of the variance are not violated. The statistical method adopted to verify normality was the Kolmogorov-Smirnov because the sample size was over $50(N=100)$ (Warner, 2013). The result of the experimental group was $p>.05$, whereas the control group result was $p>.05$. These results revealed that the assumption of normality was not violated. Therefore, the data were approximately normal for both groups. Levene's test was employed to determine the homogeneity of variance for genetic achievement scores for the experimental and control groups, which consisted of high, medium and low academic-ability students. The result for the homogeneity of variance $F$ was $(5,94)=0.351, p>.05$, indicating no statistically significant differences in the variances of the two groups. Thus, the assumption of homogeneity of variance was not violated. The significant difference in the pre-test results fulfilled one of the assumptions of the utilisation of ANCOVA. Thus, ANCOVA was utilised to analyse the data.

\section{Main and Interaction Effects}

ANCOVA was conducted to determine the main and interaction effects between the independent variables, the instructional approach and the students' academic abilities to answer the second research question. The pre-tests were utilised as the covariates. The results are presented in Table 4.

Table 4 indicates a significant main effect of the treatment (when the pre-tests are controlled) between the experimental and control groups in science achievement $F(1,93)=4.374, p(0.03)$. The partial $\eta^{2}(.05)$ indicated that $5 \%$ of the total variance was due to 
the treatment. The experimental group had a total mean of 41.14 , which was higher than the total mean of the control group at 38.59. The significant difference was in favour of the experimental group. The main effects of the students' academic abilities between the experimental and control groups was not significant $F(2,93)=$ 4.374, $p>0.05$. The partial $\eta^{2}=0.004$ indicated that the students' academic abilities contributed only $0.4 \%$ to the total variance. However, the means of the high, medium and low academic-ability students from the experimental group were higher than the means of the high, medium and low academic-ability students of the control group.

Table 4

ANCOVA Results of the Main and Interaction Effects

\begin{tabular}{|c|c|c|c|c|c|c|}
\hline Source & $\begin{array}{l}\text { Type III sum } \\
\text { of squares }\end{array}$ & Df & $\begin{array}{l}\text { Mean } \\
\text { square }\end{array}$ & $F$ & Sig. & $\begin{array}{c}\text { Partial eta } \\
\text { squared }\end{array}$ \\
\hline $\begin{array}{l}\text { Corrected } \\
\text { model }\end{array}$ & $271.33^{\mathrm{a}}$ & 6 & 45.22 & 1.05 & .39 & .06 \\
\hline Intercept & 4971.66 & 1 & 4971.66 & 115.86 & .00 & .55 \\
\hline Pre-test & 28.81 & 1 & 28.81 & .67 & .41 & .01 \\
\hline Group & 187.67 & 1 & 187.67 & 4.37 & .03 & .05 \\
\hline $\begin{array}{l}\text { Ability } \\
\text { levels }\end{array}$ & 14.61 & 2 & 7.30 & .17 & .84 & .00 \\
\hline $\begin{array}{l}\text { Group * } \\
\text { ability levels }\end{array}$ & 69.92 & 2 & 34.96 & .81 & .44 & .02 \\
\hline Error & 3990.45 & 93 & 42.90 & & & \\
\hline Total & 163383.00 & 100 & & & & \\
\hline $\begin{array}{l}\text { Corrected } \\
\text { total }\end{array}$ & 4261.79 & 99 & & & & \\
\hline
\end{tabular}

a. $R$ squared $=.064$ (Adjusted $R$ squared $=.003$ ) 
No significant interaction effects were observed between the independent variables (ability and instructional approach) $F$ (2, 93) $=.815, p(.446)>0.05$. The partial $\eta^{2}(0.02)$ revealed that the interaction effects contributed only $2 \%$ to the total variance, thereby indicating that the effects of instructional approaches on student achievement do not depend on students' academic abilities. A graph showing no interaction effects is presented in Figure 2.

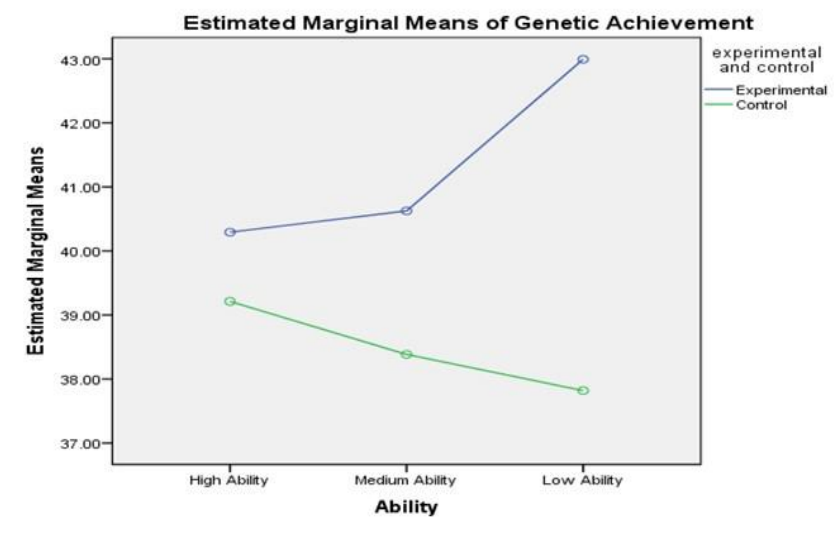

Figure 2. No Interaction Effects between the ISTEMA and Students' Academic Abilities.

Figure 2 reveals that there is no significant interaction effects observed between the ISTEMA and the students' academic abilities. The means of the high, medium and low academic-ability students in the experimental group were higher than the means of the high, medium and low academic-ability students in the control group. Consequently, the ISTEMA was effective in enhancing academic achievement amongst the students in the experimental group compared to the control group. The graph indicates that the high academic-ability students in the control group performed better than the medium and low academic-ability students in the same group. Moreover, the medium academic-ability students performed better than the low academic-ability students in the control group. Thus, there was an achievement gap between the high, medium and low academic-ability students who were taught in the traditional instructional classroom. 
Within-Group Comparison of High, Medium and Low Academic-Ability Students in the Experimental and Control Groups

Within-group comparisons (between pre-tests and post-tests) between the high, medium and low academic-ability students of the experimental and control groups were first determined utilising paired sample t-tests to answer the second research question. The results are presented in Table 5.

Table 5

Paired Sample T-Tests of High, Medium, and Low Academic-Ability Students of the Experimental and Control Groups

\begin{tabular}{llllllll}
\hline Ability & Group & $\begin{array}{l}\text { Pre-test } \\
\text { mean } \pm \text { SD }\end{array}$ & $\begin{array}{l}\text { Post-test } \\
\text { mean } \pm \text { SD }\end{array}$ & t-value & $d f$ & $p$-value & $d^{2}$ \\
High & Experimental & $34.00 \pm 7.17$ & $40.35 \pm 6.89$ & -2.58 & 14 & .02 & 0.92 \\
& Control & $34.93 \pm 6.88$ & $39.49 \pm 6.32$ & -2.09 & 14 & .054 & 0.69 \\
\hline \multirow{2}{*}{$\begin{array}{l}\text { Me- } \\
\text { dium }\end{array}$} & Experimental & $28.80 \pm 5.46$ & $40.46 \pm 6.75$ & -5.73 & 19 & .00 & 1.88 \\
& Control & $33.33 \pm 6.91$ & $38.50 \pm 6.07$ & -2.26 & 17 & .03 & 0.79 \\
\multirow{2}{*}{ Low } & Experimental & $29.19 \pm 5.71$ & $42.75 \pm 7.57$ & -6.58 & 15 & .00 & 1.81 \\
& Control & $32.63 \pm 6.40$ & $37.88 \pm 5.41$ & -2.91 & 15 & 0.01 & 0.88
\end{tabular}

Table 4 reveals that a significant mean difference can be observed between the pre-test and the post-test mean scores of the high, medium, and low academic-ability students of the experimental group; $t(14)=-2.58, p(.02)<.05 ; t(19)=-5.73, p(.00)<.05 ; t(15)$ $=-8.36, p(.00)<.05$. These results indicated that the post-test means of the high, medium and low academic-ability students were significantly higher than their pre-test means.

On the other hand, the results of the control group revealed no significant mean differences between the pre-tests and the post-tests of the high academic-ability students; $t(14)=-1.34, p(.05)>.05$; These results indicated that the post-test mean was not significantly higher than the pre-test mean. However, the within-group comparison of the post-tests of the medium and low academic-ability students of 
the control group were significantly higher than their pre-tests; $t(17)$ $=-2.26, p(.03)<.05$ and $t(15)=-2.91, p(.01)<.05$.

The effect size of the high academic-ability students of the experimental group was $\left(d^{2}=0.92\right)$, indicating a large effect size, whereas the effect size of the high academic-ability students of the control group was $\left(\mathrm{d}^{2}=0.69\right)$, indicating a medium effect size. The effect sizes of the medium academic-ability students of the experimental and control groups were $\left(d^{2}=1.88\right)$ and $\left(d^{2}=0.78\right)$, respectively, indicating a large and medium effect size for the experimental and control groups, respectively. The effect sizes of the low academic-ability students of the experimental and the control groups were $\left(d^{2}=1.81\right)$ and $\left(d^{2}=0.88\right)$, respectively. These results indicated that both groups had large effect sizes (Cohen, 1988). Given the results, the ISTEMA was more effective in enhancing science achievement amongst the high, medium and low academicability students than the traditional instructional method.

\section{Results for the High, Medium and Low Academic-Ability Students of the Experimental Group}

Analysis of variance (ANOVA) was employed to determine whether a significant mean difference existed between the high, medium and low academic-ability students of the experimental group. The results are presented in Table 6.

Table 6

ANOVA Results of the High, Medium and Low Academic-Ability Students of the Experimental Group

\begin{tabular}{lccccc}
\hline & $\begin{array}{c}\text { Sum of } \\
\text { squares }\end{array}$ & Df & $\begin{array}{c}\text { Mean } \\
\text { square }\end{array}$ & $F$ & Sig. \\
\hline Between groups & 60.75 & 2 & 30.37 & .60 & .54 \\
Within groups & 2393.28 & 48 & 49.86 & & \\
Total & 2454.03 & 50 & & & \\
\hline
\end{tabular}

Table 6 presents the ANOVA results for the high, medium and low academic-ability students. The data yielded an $F(2,48)=.60, P(0.54)$ $>.05$, hence, no significant differences were observed between the 
high, medium and low academic-ability students instructed with ISTEMA. The means were $40.47,40.35$ and 42.75 for the high, medium and low academic-ability students, respectively. Despite not having any significant differences between the three groups, the mean (42.75) for the low academic-ability students was higher than those of the high (40.46) and the medium academic-ability students (40.35). This result implies that the ISTEMA is suitable for students with different science abilities.

\section{DISCUSSION}

The present study determined the effects of the ISTEMA on the science achievements of Year 11 students. The findings revealed that a significant main effect of the treatment can be observed on the experimental and control groups when the pre-tests were controlled in favour of the experimental group. This finding signified that the ISTEMA was effective in enhancing the learning of science amongst the study population. This result concurred with the findings of other researchers who reported an improvement in student achievement when students were instructed with ISTEMAs (Sahin, Ayar, \& Adiguzel, 2014; Thomas, 2013). These studies employed elements, such as open-ended problems and engineering designs as contexts for STEM integration similar to the present study.

It would seem that science achievement in the ISTEMA group could be attributed to the iterative phases. The iterative phases of the ISTEMA provided support for students to move from one phase to another as well as back and forth. For example, the students had to generate ideas on genetic principles and laws during the ideagenerating phase and to apply the ideas to solve problems during the solution-designing phase. This approach provided the students with opportunities for minds-on activities wherein they explained and justified their ideas to one other, which may have influenced their improved understanding of genetic concepts. Thus, the application or integration of genetics in a new environment could have facilitated meaningful learning leading to enhanced science achievement amongst the experimental group.

The findings from the two-way ANCOVA revealed the absence of interaction effects between academic abilities and instructional 
approaches. This result suggested that the effects of the ISTEMA did not depend on individual students' academic abilities. Therefore, improvements in science achievements were attributed to the effects of the ISTEMA. The approach provided the students with opportunities to solve open-ended actual problems as a team. This result agreed with the literature that team projects and learnercentred activities made abstract genetic processes concrete, thereby improving student academic performance in genetics (Galloway \& Anderson, 2014; Mandusic \& Blaskovic, 2015). The practical nature of the problems could have motivated the students to engage in meaningful learning, culminating in enhanced achievement in genetics. This finding corroborated the findings of Kim, Sharma, Land, and Furlong (2013) who concluded that actual problems enhanced students' learning outcomes. Therefore, a logical conclusion is that instructional approaches characterised by defining a problem, generating ideas, designing solutions and evaluating in a collaborative environment enhance student achievement in science. The within-group comparison of the experimental and control group results revealed that high, medium and low academic-ability students gained from pre- and post-tests. However, the post-test means of the high and medium academic-ability students were higher than those of the low academic-ability students in the control group. This result concurred with Gambari et al. (2013) who reported that there was an achievement gap between low, medium, and high academic-ability students in the traditional classroom, which could be attributed to the nature and pace of traditional instruction. The pace of the traditional environment could be adequate for high academic-ability students but not for medium and low academic-ability students, indicating that the process of instruction was not suitable for students with different abilities (Steenbergen-Hu et al., 2016). Therefore, teachercentred approaches with minimal or no support may cause medium academic-ability students to lose interest in science content.

In the present study, high, medium and low academic-ability students exhibited different achievement rates which suggested that the ISTEMA instructional environment influenced students' academic achievements differently based on their academic abilities. The results indicated that high, medium and low academic-ability students benefitted; in addition, the low academic-ability students had the highest mean gain. This finding agreed with Yu et al. (2010) and Han et al. (2014), who reported that low academic-ability students performed better than high academic-ability students 
using non-traditional approaches. This result may be attributed to low academic-ability students learning in a social context through cooperation and collaboration, which is in line with Gambari et al. (2013) who determined that low academic-ability students performed on a par with high academic-ability students, if not better, in a cooperative learning setting. This ISTEMA was characterised by social interactions, students generating ideas individually and later joining groups to brainstorm ideas. The high academic-ability students appeared to support low and medium academic-ability students' learning and gained by providing answers to questions raised by the low and the medium academic-ability students. This result agreed with Vygotsky's (1978) social constructivist theory which stipulated that learning should take place in a social context. Furthermore, it also concurred with Taber (2010) who emphasised that learning in a social context suited the classroom instruction of students with different abilities.

Improvements in science achievement by the different academicability groups could be attributed to the emphasis on student-centred and independent learning with teachers as facilitators. The facilitator supports students' learning through questions that require them to reflect, think out of the box, and justify their ideas whilst assisting them to collaborate meaningfully with one another (Cohan \& Honigsfeld, 2011). These ideas seem to make learning meaningful for all the students as posited by Osman, Hiong, and Vebrianto (2013) who reported that biology instruction in the 21st century requires an interdisciplinary approach with the teacher assuming the role of facilitator.

\section{CONCLUSION}

Equity and access to science instruction for all students regardless of their abilities are of paramount importance. The ISTEMA has demonstrated improvements in the learning achievement of high, medium and low academic-ability students, thereby reducing the achievement gap between them.

The present research has provided an understanding of classroom practices, especially in the implementation of the ISTEMA, to underline that all students can learn if the correct approach is utilised. The present study indicates that student achievements can 
be enhanced through instructional environments that are studentcentred and characterised by STEM elements.

Based on the findings of this approach, it could serve as a guide for teachers to implement the ISTEMA, especially amongst students with different academic abilities, because the elements of the approach are suited for learners with different abilities (Arıkan, 2018). Furthermore, the findings of this study may encourage education policymakers to create policies involving the implementation of integrated STEM education to address learning differences amongst learners. The results of this study may assist in reducing the gap in the literature between high, medium and low academic-ability secondary school students. To consolidate these findings, a similar study may be conducted on students in different classes and settings and applied to other equity issues, such as gender, socio-economic status and school location.

\section{ACKNOWLEDGEMENT}

This research received no specific grant from any funding agency in the public, commercial, or not-for profit sectors.

\section{REFERENCES}

Acara, D., Tertemizb, N., \& Taşdemirc, A. (2018). The effects of STEM training on the academic achievement of 4th graders in science and mathematics and their views on STEM training teachers. International Electronic Journal of Elementary Education, 10(4), 505-513. doi:10.26822/iejee.2018438141

Agboghoroma, T. E., \& Oyovwi, E. O. (2015). Evaluating effect of students' academic achievement on identified difficult concepts in senior secondary school biology in Delta State. Journal of Education and Practice, 6(30), 117-125.

Arikan, E. E. (2018). A theoretical study on STEM education: Proposal of two applications. Journal of Theoretical Educational Science, 11(1), 101-116.

Atilla, C. (2012). What makes biology learning difficult and effective: Students' views. Educational Research and Reviews, 7(3), 61-71. doi:DOI: 10.5897/ERR11.205 
Berland, L., Steingut, R., \& Ko, P. (2014). High school student perceptions of the utility of the engineering design process: Creating opportunities to engage in engineering practices and apply math and science content. Journal of Science Education and Technology, 23(6), 705-720. doi:10.1007/s10956-0149498-4

Bryan, L. A., Moore, T. J., Johnson, C. C., \& Roehrig, G. H. (2016). STEM road map a framework for integrated STEM education. In C. C. Johnson, E. E. Peters-Burton, \& T. J. Moore (Eds.), Integrated STEM education. New York: Routledge.

Bybee, R. W. (2010). Advancing STEM education: A 2020 vision. Technology and Engineering Teacher, 70(1), 30-35.

Chang, Y. S., \& Yang, Y. J. (2014). An exemplar of STEM teaching design-hydraulic arm. Journal of Technology and Human Resource Education, 1(1), 2-17.

Chu, Y.-C., \& Reid, N. (2012). Genetics at school level: Addressing the difficulties. Research in Science \& Technological Education, 30(3), 285-309. doi:10.1080/02635143.2012.732 059

Cohan, A., \& Honigsfeld, A. (2011). Breaking the mold of preservice and in-service teacher education: Innovative and successful practices for the 21st century. Plymouth, UK: Rowman and Littlefield Publishers, Inc.

Cohen, J. (1988). Statistical power analysis for the behavioral sciences. Hillsdale, NJ: Erlbaum.

Danmole, B. T., \& Lameed, S. N. (2014). Exploring annotated drawing for improving Nigerian secondary school students' achievement in genetics. International Journal of Biology Education, 3(1), 1-11.

English, L. D. (2016). STEM education K-12: Perspectives on integration. International Journal of STEM Education, 3(3), 1-8. doi:10.1186/s40594-016-0036-1

English, L. D., King, D., \& Smeed, J. (2016). Advancing integrated STEM learning through engineering design: Sixth-grade students' design and construction of earthquake resistant buildings. The Journal of Educational Research, 110(3), 255-271. doi:https://doi.org/10.1080/00220671.2016.12640 53

Galloway, K., \& Anderson, N. (2014). Cootie genetics: Simulating model's experiments to understand the laws of inheritance. The American Biology Teacher, 76(3), 189-193. 
Gambari, A. I., James, M., \& Olumorin, C. C. (2013). Effectiveness of video-based cooperative learning strategy on high, medium and low academic achievers. The African Symposium: An online journal of the African Educational Research Network, 13(2), 77-85.

Guzey, S. S., Harwell, M., Moreno, M., Peralta, Y., \& Moore, T. J. (2017). The impact of design-based STEM integration curricula on student achievement in engineering, science, and mathematics. Journal of Science Education and Technology, 26(2), 207-222. doi:10.1007/s10956-016-9673-x

Guzey, S. S., Moore, T. J., \& Morse, G. (2016). Student interest in engineering design-based science. School Science and Mathematics, 116(8), 411-419.

Hair, J. F. J., Black, W. C., Babin, B. J., \& Anderson, R. E. (2010). Multivariate data analysis: A global perspective (7th ed.). Upper Saddle River, NJ: Pearson Prentice Hall.

Han, S., Capraro, R., \& Capraro, M. M. (2014). How Science, Technology, Engineering and Mathematics (STEM) projectbased learning affects high, middle, and low achievers differently: The impact of student factors on achievement. International Journal of Science and Mathematics Education, 13(5), 1089-1113. doi:10.1007/s10763-014-9526-0)

James, J. S. (2014). Science, Technology, Engineering, and Mathematics (STEM) curriculum and seventh grade mathematics and science achievement. (Ph.D), Grand Canyon University Phoenix, Arizona, (UMI: 3614935)

Karpudewan, M., \& Chong, K. M. (2017). The effects of classroom learning environment and laboratory learning environment on the attitude towards learning science in the 21st-century science lessons. Malaysian Journal of Learning and Instruction (MJLI), Special issue on Graduate Students Research on Education, 25-45.

Kermani, H. (2017). Computer mathematics games and conditions for enhancing young children's learning of number sense. Malaysian Journal of Learning and Instruction, 14(2), 23-57.

Kertil, M., \& Gurel, C. (2016). Mathematical modelling: A bridge to STEM education. International Journal of Education in Mathematics, Science and Technology, 4(1), 44-45. doi:10.18404/ijemst.95761 
Kim, K., Sharma, P., Land, S. M., \& Furlong, K. P. (2013). Effects of active learning on enhancing student critical thinking in an undergraduate general science course. Innovative Higher Education, 38, 223-235.

Kostiainen, E., Ukskoski, T., Ruohotie-Lyhty, M., Kauppinen, M., Kainulainen, J., \& Mäkinen, T. (2018). Meaningful learning in teacher education. Teaching and Teacher Education, 71, 66-77. doi:10.1016/j.tate.2017.12.009

Krajcik, J. K. (2015). Project-based science: Engaging students in three-dimensional learning. Science Teacher, 82(1), 25-27.

Lachapelle, C. P., Cunningham, C. M., Jocz, J., Kay, A. E., Phadnis, P., Wertheimer, J., \& Arteaga, R. (2011). Engineering is Elementary: An evaluation of years 4 through 6 field testing. Paper presented at the NARST Annual International Conference, Orlando, FL.

Lin, S., \& Lin, H. (2016). Learning nanotechnology with texts and comics: The impacts on students of different achievement levels. International Journal of Science Education, 38(8), 1373-1391. doi:10.1080/09500693.2016.1191089

Lottero-Perdue, P., Roland, C., Turner, K., \& Pettitt, J. (2013). Learning about the engineering design process through earth science. Science Scope, 36(6), 62-72.

Mandusic, D., \& Blaskovic, L. (2015). The impact of collaborative learning to critically think. Trakia Journal of Science, 13(Suppl.1), 426-428. doi:10.15547/tjs.2015.s.01.073

Martinez, S. L., \& Stager, G. (2013). Invent to learn: Making, tinkering, and engineering in the classroom. Torrance, CA.: Constructing Modern Knowledge Press.

Osman, K., Hiong, L. C., \& Vebrianto, R. (2013). 21st century biology: An interdisciplinary approach of biology, technology, engineering and mathematics education. Procedia - Social and Behavioral Sciences, 102, 188-194. doi:10.1016/j. sbspro.2013.10.732

Osman, K., \& Saat, R. M. (2014). Editorial Science Technology, Engineering and Mathematics (STEM) education in Malaysia. EURASIA Journal of Mathematics, Science \& Technology Education, 10(3), 153-154.

Raes, A., Schellens, T., \& De Wever, B. (2013). Web-based collaborative inquiry to bridge gaps in secondary science education. The Journal of the Learning Sciences, 23(3), 316347. 
Rinke, C. R., Gladstone-Brown, W., Kinlaw, C. R., \& Cappiello, J. (2016). Characterizing STEM teacher education: Affordances and constraints of explicit STEM preparation for elementary teachers. School Science and Mathematics, 116(6), 300-309.

Sahin, A., Ayar, M. C., \& Adiguzel, T. T. (2014). STEM related after-school program activities and associated outcomes on student learning educational sciences. Theory \& Practice, 14(1), 309-322.

Sailin, S. N., \& Mahmor, N. A. (2018). Improving student teachers' digital pedagogy through meaningful learning activities. Malaysian Journal of Learning and Instruction, 15(2), 143173.

Sanders, M. (2009). STEM, STEM education, STEMania. The Technology Teacher, 48(4), 20-26.

Schofield, J. W. (2010). International evidence on ability grouping with curriculum differentiation and the achievement gap in secondary schools. Teachers College Record, 112(5), 14921528.

Shahali, E. H. M., Halim, L., Rasul, M. S., Osman, K., \& Zulkifeli, M. A. (2017). STEM learning through engineering design: Impact on middle secondary students' interest towards STEM. EURASIA Journal of Mathematics, Science and Technology Education, 13(5), 1189-1211. doi:10.12973/ eurasia.2017.00667a

Steenbergen-Hu, S., Makel, M. C., \& Olszewski-Kubilius, P. (2016). What one hundred years of research says about the effects of ability grouping and acceleration on K-12 students academic achievement: Findings of two second-order metaanalyses. Review of Educational Research, 86(4), 849-899. doi:10.3102/0034654316675417

Stohlmann, M., Moore, T., \& Roehrig, G. H. (2012). Considerations for teaching integrated STEM education. Journal of PreCollege Engineering Education Research, 2(1), 28-34. doi: $10.5703 / 1288284314653$

Stohlmann, M. S., Moore, T. J., \& Cramer, K. (2013). Pre-service elementary teachers' mathematical content knowledge from an integrated STEM modelling activity. Journal of Mathematical and Application, 1(8), 18-31.

Taber, K. S. (2010). Challenging gifted learners: General principles for science educators; and exemplification in the context of teaching chemistry. Science Education International, 21(1), $5-30$. 
Thalib, M., Corebima, A. D., \& Ghofur, A. (2017). Comparison on critical thinking skill and cognitive learning outcome among students of $\mathrm{X}$ grade with high and low academic ability through reading questioning answering (RQA) strategy. Jurnal Pendidikan Sains, 5(1), 26-31.

Thomas, M. E. (2013). The effects of an integrated S.T.E.M. curriculum in fourth grade students' mathematics achievement and attitudes (PHD), Trevecca Nazarene University, Nashville, ProQuest LLC (2013). Retrieved from https://search.proquest.com/docview/1413329612?Account id=7374 (UMI 3565696)

Treacy, P., \& O'Donoghue, J. (2014). Authentic integration: A model for integrating mathematics and science in the classroom. International Journal of Mathematical Education in Science and Technology, 45(5), 703-718. doi:10.1080/002 0739x.2013.868543

Tsai, H.-Y., Chung, C.-C., \& Lou, S.-J. (2018). Construction and development of iSTEM learning model. EURASIA Journal of Mathematics, Science and Technology Education, 14(1), 15-32. doi:10.12973/ejmste/78019

Vygotsky, L. S. (1978). Mind in society: The development of higher psychological processes. Cambridge, MA: Harvard University Press.

Williams, M., Montgomery, B. L., \& Manokore, V. (2012). From phenotype to genotype: Exploring middle school students' understanding of genetic inheritance in a web-based environment. The American Biology Teacher, 74(1), 35-40. doi:10.1525/abt.2012.74.1.8

Yu, W. F., She, H. C., \& Lee, Y. M. (2010). The effects of web-based/non-web-based problem-solving instruction and high/low achievement on students' problemsolving ability and biology achievement. Innovations in Education and Teaching International, 47(2), 187-199. doi:10.1080/14703291003718927 